Ярослава Свяченая.

Национально-патриотическое воспитание студенческой молодежи: проект «Харьков - город патриотов».

Проанализировано современное состояние проблемы нащиональнопатриотического воспитания студенческой молодежи. Освещены нормативно-правовые документы по указанной проблемы. Разработан проект: «Харьков - город патриотов». Раскрыта суть и особенности поэтапной реализации проекта.

Ключевые слова: национально-патриотическое воспитание, студенческая молодежь, патриотизм личности, проект.

Yaroslava Svyachenaya. National-patriotic education of students: the project «Kharkov - the city of patriots».

The current state of the problem of national-patriotic upbringing of student youth is analyzed. The normative-legal documents on the mentioned problem are covered. The project was developed: "Kharkiv is a city of patriots». The essence and features of the phased implementation of the project are revealed.

Keywords: national-patriotic education, student youth, patriotism personality, project.

Стаття надійшла до редакційної колегії 01.04.2017

UDC 159.955.2:37.013.2"20"-027.512

Slivak Viktoriia

Igor Sikorsky Kyiv Polytechnic Institute

\title{
THE NOTION OF CONTEMPORARY SPECIALIST FORMATION THROUGH THE PRISM OF PSYCHOLOGY AND PEDAGOGY
}

This article is dedicated to the notion of psychological and pedagogical impacts on the process of specialist formation. A lot of attention is initially paid to the general understanding of the role of psychology and pedagogy in this process that eventually directly influences the development of a modern specialist.

Keywords: the formation of a specialist, psychology, pedagogy, pedagogical phycology, society, contemporary specialists, pedagogical approach, psychological approach.

Introduction. Nowadays the role of the psychological and pedagogical aspects of formation of the professional competence of the future specialists are usually underestimated if not neglected at all by the 
scientists and the society in general. There are not enough scientific works that cover this topic in psychology and as the result the level of awareness regarding such notions in the people's minds is low too, no matter how important and useful these concepts are.

The aim of this article is to draw the attention of world's society to the notion of contemporary specialist formation that occurs through the prism of psychology and pedagogy.

Analysis of the last scientific works. The subject of this article is unexplored neither in the scientific works of Ukrainian scientists nor in the foreigners'. Some of scientists, like V. Kobulchenko, do pay attention to the general concept of personality formation under the agenda of pedagogical psychology, however the main question -how is the specialist formation influenced through psychology and pedagogy remains unanswered.

Results. To begin with, it is important to understand what is meant under the terms of «psychological and pedagogical impacts» and only then investigate the role of the mentioned impacts on the development of modern specialists. First of all, it is noteworthy to mention that the process of specialist formation can be considered through the prism of two branches of science: psychology and pedagogy. "This literally means that there are psychological and pedagogical conditions required for the formation of a professional to take place. On the one hand, the first one foresees the formation of a specialist through the development, process and result of psychic activity of an individual» [1]. «In this case the formation is an object of psychological sciences that investigate the laws, regularities and manifestations of the physic of the future specialist. This is considered to be a so-called psychological approach or method that tries to figure out what a specialist has inside its personality at that certain moment and what can be developed from it later due to the purposeful actions» [1].

On the other hand, the formation of the modern specialist can be considered in the context of its upbringing or with the help of another branch of science - pedagogy. «The pedagogical approach is aimed at understanding what has to be formatted in the specialist so that he could correspond to the social demands that are required by a society from both an individual and a professional» [1].

The importance of the equal influence of these two branches of science gives us opportunity to combine their general impact in one notion that was granted the name - pedagogical psychology - one of the most important branches of psychological science. «The basis of allocation of this branch of psychology is the psychological aspect of concrete activity of teaching, training. Two other classification bases of psychological branches are psychological aspect of development and the relation of the person to society are highlighted on these grounds, such as age and social psychology» [2]. 


\section{Збірник наукових статей}

Secondly, after getting familiar with the theoretical notion of the psychological and pedagogical approaches in the formation of a specialist, it is possible to start the investigation of its practical usage. My point of view is that the contemporary specialist formation comes through the prism of psychology and pedagogy in two stages: first of all, through described earlier psychological method, we can get familiar with the talents, character, habits and possibilities of a potential specialist. Then, due to pedagogical methods the skills, habits and all the set of the possibilities of the specialist is adopted to the demands of the society and social understanding. For example, children learn how to use their knowledge in the frames of school during the lessons and while communicating with their classmates. This is the starting point for both approaches. Then, later at the university the pedagogical approach starts to prevail: professors step by step adopt the new knowledge of students and the old school skills to the demands of the market and society. This mechanism continues even afterwards after graduation when people who are already specialists acquire even more skills and experience during their work and try to find its' use and the correspondence of the new experience and habits to the eternally-changing world and to the society as a form of its manifestation.

Conclusions. All things can considered, it can be summarized that psychology and pedagogy, manifested in appropriate approaches, play an important and determinative role in the formation of a specialist in a contemporary world. What is more, the importance of their influence is also supported by the fact that they continue to have a certain impact on the individual during different stages of life: from the very beginning at school to the most conscious ages when a specialist is already formed. For these reasons, the notion of a modern specialist formation through psychology and pedagogy has to be estimated more seriously with appropriate scientific attention and future investigations.

\section{References}

1. Кобильченко В. В. Формування особистості як психологопедагогічна проблема [Електронний ресурс] / В.В.Кобильченко. Режим доступу: http://irbis-nbuv.gov.ua/cgibin/irbis_nbuv/cgiirbis_64.exe.PDF/ooop_2012_3\%281\%29_12.pdf.

Назва $з$ титул. екрану.

2. Marchibayeva Ulbosyn. Psychological aspects of formation the professional competence of the future specialists [Online resource]/ Marchibayeva Ulbosyn, Tazhigulova Batima, Omarov Yessen, etc. Access mode: http://ac.els-cdn.com/S1877042815021588/1-s2.0S1877042815021588-main.pdf?_tid=a46733da-44ae-11e7-83b600000aab0f6c\&acdnat $=1496090433 \_124503 d 1$ cc589a79f4d7583f1c089162 . - Name from the title screen. 
Вікторія Слівак. Поняття формування сучасного спеціаліста через призму психології і педагогіки.

Ця стаття присвячена поняттю психологічних і педагогічних впливів на прочес формування спеціаліста. Багато уваги приділяється спочатку загальному розумінню ролі психології $i$ педагогіки у иьому процесі, яка зрештою виражається у прямому ї̈ впливі на розвиток сучасного спеціаліста.

Ключові слова: формування спеціаліста, психологія, педагогіка, педагогічна психологія, суспільство, сучасні спещіалісти, педагогічний nідхід, психологічний підхід.

Виктория Сливак. Понятие формирования современного специалиста сквозь призму психологии и педагогики.

Эта статья посвящена понятию психологических и педагогических влияний на процесс формирования специалиста. Много внимания уделено сначала общему пониманию роли психологии и педагогики в этом прочессе, которая в конечном итоге, выражает свое прямое влияние на развитее современного специилиста.

Ключевые слова: формирование специалиста, психология, педагогика, педагогическая психология, общество, современные спечиалисты, педагогический подход, психологический подход.

Стаття надійшла до редакційної колегії 30.05.2017

\section{УДК 37.091.2::614.253.4]:167.1-316.62GOOGLE}

(C) Станин Д. М., Сединкин В. А., 2017

Станин Дмитрий Михайлович,

Сединкин Владислав Анатольевич

Государственное учреждение

«Днепропетровская медицинская академия МЗ Украины»

\section{ПРОБЛЕМА «ЭФФЕКТА GООGLЕ» В ПРОЦЕССЕ ПОДГОТОВКИ МОЛОДОГО СПЕЦИАЛИСТА}

Проанализирована проблема «эффекта Google» и ее влияние на процесс обучения врачей-интернов. Предложены варианты решения данного вопроса при проведении практических занятий в программе подготовки будущего специалиста.

Ключевые слова: «эффект Google», врачи-интерны, последипломное образование. 